\title{
EQUILIBRIUM
}

Quarterly Journal of Economics and Economic Policy

VOLUME 7 ISSUE 1, 2012

ISSN 1689-765X

\author{
Iwona Szczepaniak* \\ Institute of Agricultural \\ and Food Economics -National \\ Research Institute, Poland
}

\section{The Global Economic Crisis AND The CoMpetiveness of Polish Food Producers}

JEL Classification Codes: D24, L66

Keywords: economic crisis, competitiveness, food industry

\begin{abstract}
The objective of this study is to show the influence of world economic crisis on economic situation of Polish food industry and competitiveness of Polish food producers. The study is an analysis based on statistical data. A complement of the analysis is a theoretical consideration based on topical literature and the author's own reflections. Because of development of world economy globalization processes, world economic crisis has an influence on every country in the world, both the most advanced and developing ones. The confidence in banking system has been decreasing along with a dramatic slowing down of the economic development and the economic recession. It was manifested, first of all, in the most advanced countries of the world (USA, EU, Japan) and in a part of developing countries (Russia, Ukraine). The consequences of world economic crisis are also reflected in Polish economy, but it was resistant to the crisis phenomena and there was only a slowdown of its development (from among all countries of the EU, only
\end{abstract}

(C) Copyright Nicolaus Copernicus University Press

Date of Submission: March 6, 2011; date of acceptance: October 18, 2011

* Contact: e-mail: szczepaniak@ierigz.waw.pl, Instytut Ekonomiki Rolnictwa i Gospodarki Żywnościowej - Państwowy Instytut Badawczy, ul. Świętokrzyska 20, 00-002 Warszawa, Poland 
in Poland there was an increase of GDP). Even less sensitive to the crisis was the Polish food sector, including food industry. It was the branch of industry in which the slowdown of production development, national demand and export, with the meaningful reduction of import and investments were only transitory phenomenon (2008). After short-term deteriorations of results, food industry has even reached record economic-financial results (2009-2010). The general animation of the Polish economy has also come back. This indicates the return of developmental tendencies in Polish food industry. The coming years should be a period of further development of this sector, but at a slower rate than in the years of Poland integration with the European Union (2003-2007).

\section{INTRODUCTION}

A crisis not only disrupts the economic potential, eliminates weak operators, but it also destroys many elements and ways of previous understanding of reality.

Szymański $(2009$, p. 7)

The environment where enterprises, industries, sectors or national economies operate is characterised by discontinuous processes and unpredictable developments. It results in increased risk and uncertainty in business. There is even a notion of a "turbulent environment", i.e. a tempestuous one with disorderly, chaotic, multidirectional and multilevel changes. In such an environment, there are situations favourable for companies and conducive to enterprise development as well as situations posing threats to businesses (e.g. crises). The ability to adapt to or anticipate them determines the likelihood of obtaining a competitive advantage by an individual company (Szczepaniak 2009, p. 124). According to Wiatrak, the use of internal factors influencing the competitiveness of businesses depends on external factors shaping the arena of competition and its course (Wiatrak 2008, p. 9). In the face of the global economic crisis, it seems relevant to explore this aspect of competitiveness.

In general, competitiveness is understood as obtaining an advantage in the market in goods and services. The studies conducted by IERiGZ̈-PIB show that food producers in Poland should be competitive in relation to the companies operating in the common European market (CEM) as well as in third markets. It resulted in defining the competitiveness of food producers as the ability to enter foreign markets by domestic producers and their ability to develop effective exports (Szczepaniak 2009, p. 119). Such an 
approach is consistent with the generally adopted OECD definition, from which it follows that the competitiveness of an economy is its ability to cope with international competition, i.e. to realise significant exports and maintain a high level and growth rate of domestic demand without deteriorating the current account balance (Skawińska 2002).

As Szymański puts it, "The world and its problems in the process of globalisation have become extremely interrelated" (Szymański 2009, p. 7). Thus, the world economic crisis has been obviously affecting the general economic situation in Poland as a threat to its development. This influence has been mostly reflected in the deteriorated global growth, limited lending activity and restricted access to external funding, and consequently in unfavourable changes in the real sector. The crisis has become the most important cause of the economic slowdown observed in Poland from mid-2008 to the end of 2009.

International experience shows that the development prospects for particular sectors decreasingly result from their endogenous conditions and increasingly depend on sectoral policies, primarily on the macroeconomic policy. Therefore, growth trends observed in the economy as a whole are of paramount importance to the competitiveness of the food sector. Positive results obtained on a macroeconomic scale are transmitted to the food industry and its environment. GDP growth stimulates disposable income, which in turn fuels final demand for food products. Under market economy conditions, the demand for such products determines the economic situation in the agri-food market. Food market conditions represent an integral part as well as a consequence of the overall economic situation. Thus, the economic and financial standing of the food industry and the competitiveness of food producers largely depend on general economic developments.

The implications of the global economic crisis for the Polish agrifood sector and for Poland's entire economy have been mitigated by the fact that Poland became a European Union Member State (although it is not necessarily true of all the countries acceding to the EU in 2004). It essentially changed the economic conditions for the functioning of Polish food producers and contributed to the accelerated growth of the Polish food sector.

Apart from macroeconomic and global conditions, the main cause of such changes was Poland's joining the common European market (CEM), thus the inclusion of the Polish economy in the free trade area. After Poland's accession to the European Union, Polish producers have developed their links with the international market, which is reflected, among other things, by the results of foreign trade in agri-food products. Over the seven years of Poland's membership of the EU, there has been a buoyant (nearly 3.5-fold) increase in exports of Polish agri-food products, which more than 
compensated for the slower growth (threefold) in agri-food imports. Furthermore, there has been a marked (over sixfold) rise in the value of agrifood trade balance. Polish food producers have considerably improved their competitive position in the enlarged EU market. The share of exports in the total sales of the food industry exceeded $25 \%$. However, such a strong export orientation of the Polish agri-food sector has made it more sensitive to any changes in international markets. Recently, such developments have been mainly determined by the global economic crisis.

The impact of the global economic crisis on the food sector in Poland also stemmed from the fact that the main food production functions of the sector in question have been increasingly performed not only by agriculture and the food industry, but by an entire complex of activities shaped by various factors and conditions independent of the food sector.

This paper aims to present the influence of the global economic crisis on the economic situation of the Polish food industry and on the competitiveness of Polish food producers, thus, in other words, to discuss the changes observed in the food industry and its environment during the crisis. The assessment is preceded by a brief description of crisis developments in Poland as compared to other European Union Member States.

It is an analysis based on statistical data, complemented by theoretical considerations drawing on the relevant literature and the author's own reflections.

\section{POLAND'S ECONOMY IN THE GLOBAL ECONOMIC CRISIS}

\section{General remarks}

Modern economic crises represent very complex phenomena, from their inception to transmission mechanisms and dynamics to their implications. As a rule, however, the roots of crises should be sought in the functioning of monetary and banking markets, businesses and other real-sector operators as well as in government activities (policies). Since the links multidirectional and strongly interrelated, they are not yet fully recognised.

The recent crisis primarily concerned the financial system and the banking sector, as well as the real estate market. There was a dramatic plunge in the liquidity of the banking system and the confidence in this system collapsed. The crisis broke out in the very centre of the world economy, i.e. in the United States, but close capital, commercial and production links made it spread quickly to other, also European, countries. The crisis hit advanced economies faster and to a larger extent than it was the case with the devel- 
oping countries. The turbulence in financial markets observed in 20082009 very quickly spread to raw material markets, including agri-food markets, which resulted in increasing volatility of parameters determining the economic and financial standing of the food sector. Thus, the financial crisis affected the real economy. The crisis was mainly characterised by the following:

- owing to the development of globalisation processes in the world economy, the crisis has also become global and hit both developed and fastdeveloping countries;

- due to the complexity of the modern financial system and strong interrelations between particular components as well as to the role of this system in stimulating demand and markets, the crisis has affected all areas of economic life (Urban 2009, p. 2).

The collapse in the financial system had not been anticipated and occurred in a period of very favourable global economic conditions, the world's largest economies noted high GDP growth rates and many fastdeveloping countries recorded economic growth rates exceeding $10 \%$ in annual terms. The global growth trends plummeted much more dramatically than expected.

Initially, the crisis spared the Polish economy, although developments such as a dangerous dependence of the value of the Polish zloty on speculative short-term investments, high public debt and a considerable share of imports in production posed the main threats to Poland's economy. Subsequently, there were other factors of crisis transmission to Poland, e.g. limited lending activity by international banks, exchange rate fluctuations and financial problems faced by enterprises. However, Poland still earned rather positive assessments in comparison with other European economies.

This relatively mild course of the crisis in the Polish economy (as compared to other countries in the region) resulted from a number of factors, mostly from the fact that Poland decelerated from a high (more than 5\%) GDP growth rate, it implemented EU-funded investments, the weakening of the zloty improved competitiveness, and it benefited somewhat from its economic underdevelopment. This underdevelopment was reflected in a rather limited role of exports, a high share of internal demand in domestic demand, a low level of specialisation, i.e. considerable diversification of production, a low share of loans in financing current and investment needs of enterprises, limited interest in consumer credits, as well as in underdeveloped investment funds and a rather traditional behaviour of banks. The above-mentioned factors combined to create a "cushion" for the Polish economy (Szymański 2009, p. 198; Szymański 2010, pp. 27-28). There were also positive influences of the following: a relatively flexible labour market, the "free rider" effect, i.e. benefiting from fiscal and monetary 
stimulus packages introduced by Poland's main trading partners, avoiding major mistakes in macroeconomic policy, prudence displayed by employees and employers, preventing speculative bubbles in markets in nonfinancial and financial assets, preventing over-investment without dramatic reductions in investment loans in the economy (Wptyw... 2010, p. 11). The economy also benefited from decisions made previously in the periods of favourable market conditions, e.g. from cuts in taxes and disability contributions. It stimulated disposable income and helped maintain demand in spite of crisis developments (Szymański 2010, p. 28).

Some of the above-mentioned represented one-off factors, therefore they cannot be treated as substitutes for necessary fiscal and structural reforms or as preconditions for building long-term macroeconomic stability and sustainable economic growth, but they played an unprecedented role in the crisis (Wptyw... 2010, p. 11). As Szymański puts it, nothing is free in economics, for certain decisions Poland has paid with a worsened situation in public finance, which will hamper Poland's recovery from the crisis. There has been a marked slowdown in economic growth and a deterioration in budgetary imbalance, as reflected in an increased budget deficit and public debt. Moreover, the structural, technological and systemic underdevelopment which previously protected the economy against the effects of the crisis now gradually becomes a barrier to achieving rapid growth (Szymański 2010, p. 28).

\section{The dynamics of the main macroeconomic}

\section{indicators in Poland and in the European Union}

According to economists' assessments, an economic recession occurs when gross domestic product (GDP) continues to decline for two consecutive quarters. In 2009 such developments were observed in all the European Union Member States - with the exception of Poland. When the recession was at its worst, i.e. in the $2^{\text {nd }}$ and $3^{\text {rd }}$ quarters of 2009, the GDP in the EU dropped by an average of $4.7 \%$. The Baltic States, i.e. Estonia, Lithuania and Latvia, were among those hardest hit by the recession (16.6\% on average). Deep recessions affected eleven EU Member States (5-10\%), including the Scandinavian countries (Denmark, Finland and Sweden), Germany, the United Kingdom, Ireland, Italy, Hungary, Slovenia, Slovakia and Luxembourg. In other EU Member States the decreases in Gross Domestic Product ranged from $2 \%$ to $5 \%$, whereas a rise in GDP, by $1.2 \%$, was solely noted in Poland ${ }^{1}$.

\footnotetext{
${ }^{1}$ The assessment of the recession and of the subsequent recovery is based on quarterly data describing the main macroeconomic indicators in the EU Member States, published in relevant issues of Biuletyn Statystyczny (Statistical Bulletin) GUS, 2009-2011.
} 
Figure 1. Dynamics of GDP, industrial production, private consumption and prices in the EU and in Poland (in \%, on the corresponding period of the previous year)
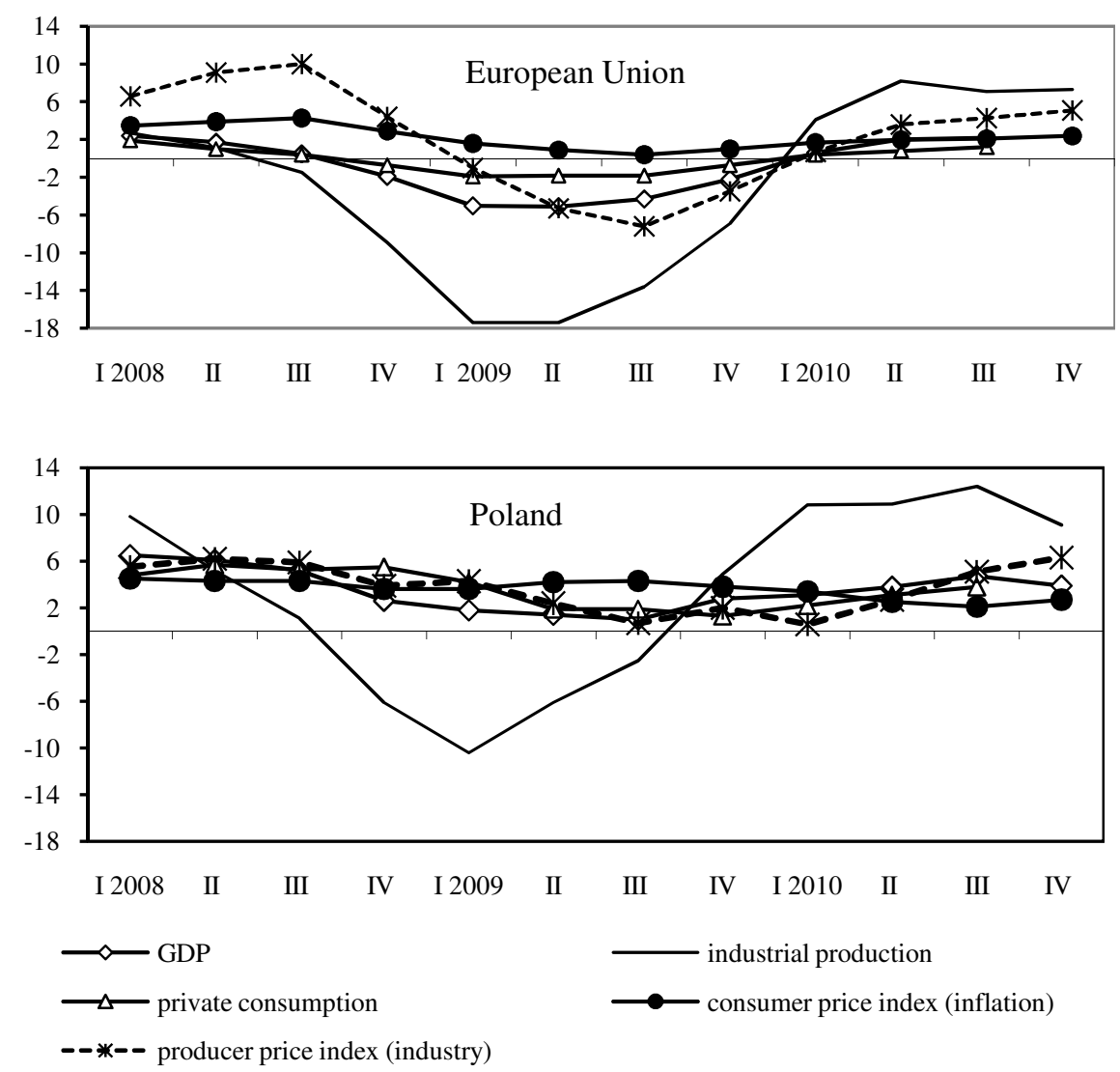

Source: own study based on Biuletyn Statystyczny (Statistical Bulletin), GUS (2009-2011), relevant issues.

The recession has hit industrial enterprises the most. In the $2^{\text {nd }}$ and $3^{\text {rd }}$ quarters of 2009, industrial production in the European Union was on average $15.4 \%$ lower than in the corresponding period of 2008. The sharpest fall in production was noted in the countries such as Estonia (29\%), Finland $(23 \%)$, Slovenia (22\%), Italy (21\%), as well as Bulgaria and Hungary (20\% each). The mildest decreases in industrial production were observed in Poland (4\%), as well as Ireland (3\%), Romania (7\%), Portugal and Cyprus (9\% each). In the remaining EU Member States, industrial production dropped by over $10 \%$. The falling production was followed by dramatic reductions in industrial producer prices. Whereas in previous periods those 
prices in the EU rose by ca. $10 \%$ in annual terms, in the $2^{\text {nd }}$ and $3^{\text {rd }}$ quarters of 2009 they went down by more than $6 \%$. Thus, EU industry experienced deflation phenomena typical of a recession. They were not observed in Poland, although the growth rate of industrial producer prices declined from approx. $6 \%$ before the recession to $2.4 \%$ in the $2^{\text {nd }}$ quarter and to $0.7 \%$ in the $3^{\text {rd }}$ of 2009 .

At the same time, deflation was not noted at consumer level, even though the growth rate of consumer prices in the EU dropped from ca. $4 \%$ in mid-2008 to $0.6 \%$ in the $2^{\text {nd }}$ and $3^{\text {rd }}$ quarters of 2009. Regarding Poland, in all the quarters of the previous two years the inflation rate remained stable and high (at approx. 3.5-4.5\% in annual terms), and in the $2^{\text {nd }}$ and $3^{\text {rd }}$ quarters of 2009 it ran at $4.3 \%$. It means that consumers were affected by the recession to a lesser degree. The EU rate of decline in private consumption was 2.5 times lower than in the case of GDP; before the recession, private consumption in the EU augmented by an average of $1-2 \%$ in annual terms, whereas in the $2^{\text {nd }}$ and $3^{\text {rd }}$ quarters of 2009 it fell by $1.9 \%$. At the same time, prior to the global crisis, Poland's private consumption increased at an annual rate of ca. 5-6\%, whilst in the $2^{\text {nd }}$ and $3^{\text {rd }}$ quarters of 2009 the growth rate in question went down to $2.6 \%$. The slowdown in domestic consumer demand was considerable as the growth rate more than halved, but it was still similar to figures noted previously in the developed EU countries.

The main macroeconomic indicators corroborate the assertion of a deep recession in European Union Member States in 2009 and of Poland being "a green island in a red sea of recession" as it merely experienced an economic slowdown. As a matter of fact, Poland was even referred to as the European leader in combating the crisis. Poland enjoyed that advantageous situation due to a number of favourable circumstances such as the inflow of EU funds fuelling investment and the depreciation of the zloty against the euro enhancing the profitability of export transactions.

At the same time, macroeconomic indicators demonstrate that the EU economy is recovering. As early as the $4^{\text {th }}$ quarter of 2009 , the EU's GDP declined by a mere $2.2 \%$ and then went up by $0.6 \%$ in the $1^{\text {st }}$ quarter of 2010. The subsequent quarters of 2010 witnessed further increases in GDP: in the $2^{\text {nd }}$ and $3^{\text {rd }}$ quarters it rose by $2.0 \%$ and $2.2 \%$ respectively (i.e. it grew by $1.6 \%$ in the first three quarters of 2010). From the $1^{\text {st }}$ to $3^{\text {rd }}$ quarters of 2010, a fall in GDP was only recorded in five EU Member States (Greece, Romania, Ireland, Spain and Bulgaria), and industrial production dropped in two countries (Greece and Cyprus), whereas across the EU it went up by an average of $6.5 \%$. An upward trend of producer prices reappeared (on average, up by $1.9 \%$ in the EU) and consumer prices accelerated (a rise by $2.9 \%$ ). At the same time, Poland again experienced an economic upturn as 
the GDP growth rate augmented to $2.8 \%$ in the $4^{\text {th }}$ quarter of 2009 , and in subsequent quarters of 2010 it reached $3.1 \%, 3.8 \%$ and $4.7 \%$ respectively (from the $1^{\text {st }}$ to $3^{\text {rd }}$ quarters of 2010: $3.9 \%$ ). At present, the growth rate of industrial production in Poland (from the $1^{\text {st }}$ to $3^{\text {rd }}$ quarters of 2010: $11.4 \%$ ) even exceeds the figure noted immediately before the global crisis. However, other EU Member States will not recover as soon as Poland, whereas the upswing noted in Poland will not be as significant as that observed during Poland's integration into the EU.

According to the forecasts of the International Monetary Fund (World... 2011) $)^{2}$, in 2011 and 2012 the EU Member States will note annual GDP growth rates of ca. $1.5 \%$ and $1.7 \%$ respectively, whereas the respective figures for Poland will be $3.6 \%$ and $4.0 \%$ (the budget act for 2011 assumes that the Polish economy will grow at a rate of $3.5 \%$ ). The growth rates of the EU's GDP will be lower than those for the USA (3.0\% and 2.7\%), Russia $(4.5 \%$ and $4.4 \%)$, India (8.4\% and $8.0 \%)$ and China (9.6\% and $9.5 \%)$. GDP for the global economy is estimated to go up by $4.4 \%$ in 2011 and by $4.5 \%$ in 2012. Economic growth in the EU and in Poland should be maintained by domestic demand, driven by greater EU-funded public investment, increased lending and an improved financial standing of private businesses conducive to investments. At the same time, one of the obstacles to the economic growth of the Community will be the crisis in public finance and substantial public debt, as well as the high unemployment rate, undermining internal demand. The IMF have warned, especially, of the risk involved in the indebtedness crisis faced by the majority of euro-area countries, which makes global financial stability uncertain.

\section{IMPLICATIONS OF THE CRISIS FOR POLISH FOOD PRODUCERS}

\section{The Warsaw Stock Exchange quotations}

The global turbulence which hit Poland hard affected the Polish food sector as well. Although the Polish banking system is assessed as relatively safe, in the past four years there have been significant movements in quotations at the Warsaw Stock Exchange (Warsaw... 2011). The listed companies usually include the most creative businesses which become the "gauge" of trends observed in the economy as a whole and in specific industries. At the end of December 2008, the main stock market indices (WIG, WIG20 and WIG-SPOŻ) were on average 50-60\% lower than those recorded a year

\footnotetext{
${ }^{2}$ The outlook of 25 January 2011, more favourable than that published in October 2010.
} 
before. In the $1^{\text {st }}$ quarter of 2009 they continued to decline (at the end of the quarter in question being ca. 15-20\% lower than at the end of 2008), and only subsequent quarters of the year witnessed a rise in quotations. Starting from mid-2009, all the stock market indices have shown an upward trend, with the growth rate of the WIG-SPOŻ index distinctly exceeding that of the WIG20 index. The gap between the indices in question widened in subsequent quotations.

Figure 2. WIG, WIG20 and WIG-SPOŻYWCZY (from $3^{\text {th }}$ January 2007 to $18^{\text {th }}$ February 2011)

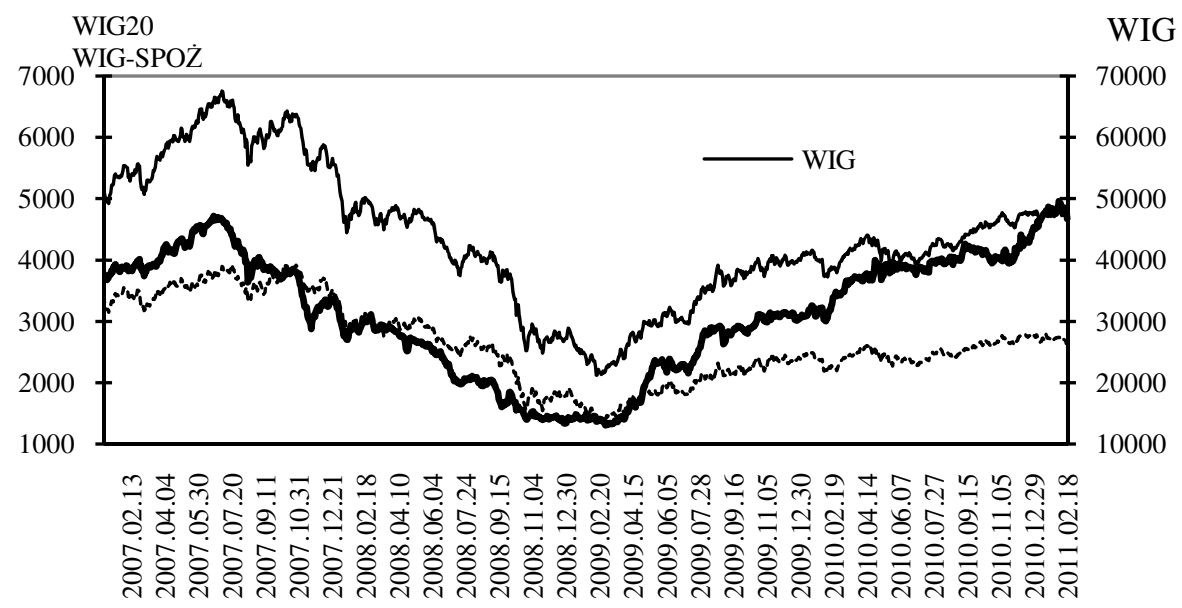

Source: own study based on the Warsaw Stock Exchange quotations, www.money.pl.

In 2010 WIG-SPOŻ continued to grow markedly faster than WIG. Throughout 2010, WIG-SPOŻ increased nearly by $46 \%$, and by as much as over $246 \%$ in comparison with the lowest level in the cycle (in March 2009). At the end of December 2010, it was only 4.7\% below the 2007 peak (4750 points), exceeding that record-high level as early as in February 2011. It confirms the good economic and financial standing of food companies, investors' rising interest in the Polish agri-food market and an upturn in the Polish food sector.

\section{Production results of the food industry}

After a few years of robust sales in the food industry, the upward trend collapsed. Whereas in the $1^{\text {st }}$ quarter of 2008, as between 2003 and 2007, 
the annual growth rate of sold production was high at 6-7\% at constant prices, in the second half of the year it dropped considerably. The first five months of 2009 saw a further decline in sales of food and beverages, but they picked up markedly in the second half of the year. Similar trends were observed in 2010 as substantial increases in production were noted nearly in all months. Importantly, the dynamics of sales of food and beverages significantly exceeded the figures for Poland's industry as a whole, even in periods of decline. It may suggest that the food sector was more resistant to crisis developments than the Polish economy.

Figure 3. Dynamics of sold production of food and beverages ${ }^{\mathrm{a}}$ (corresponding period of the previous year $=100$ )

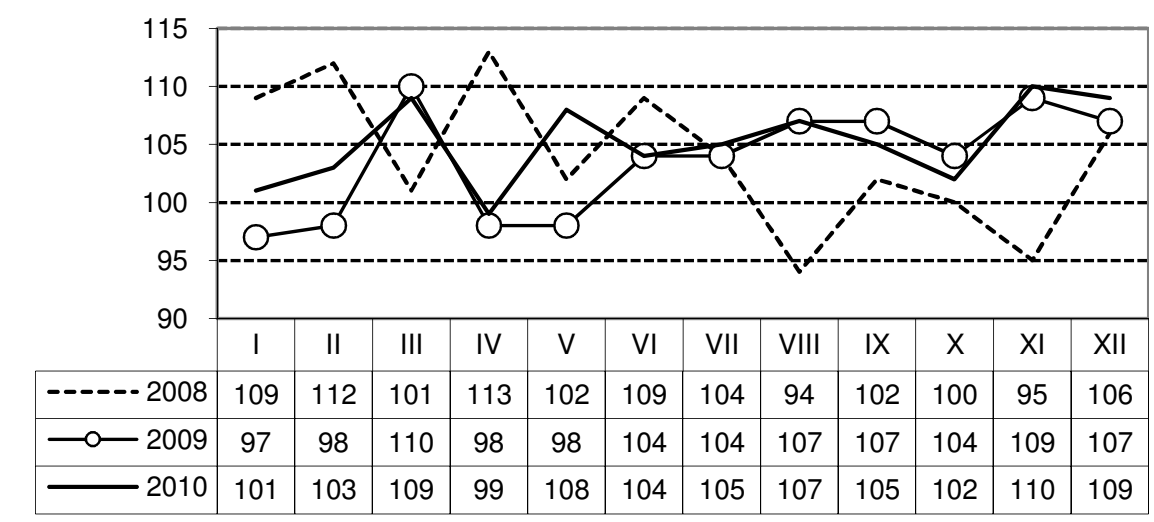

${ }^{a}$ the data concern large and medium-sized enterprises.

Source: own study based on Biuletyn Statystyczny (Statistical Bulletin), GUS (2008-2011), relevant issues.

The analysis of annual trends in sales of the food industry confirms the acceleration noted in 2005-2007 and a marked slowdown in production in 2008. Throughout 2008, the value of the sold production of the food industry at constant prices rose by a mere $2.0 \%$. Crisis developments were not the only reason for the deteriorated production performance of the food industry in 2008 and in the first months of 2009. It was also contributed to by a deep trough in the pigmeat cycle, the reform of the sugar market and a drop in sugar production, as well as by problems encountered in the biofuel sector. Those factors combined brought about a sharp output contraction in these sectors of the food economy.

The last months of 2009 turned out to be much more favourable for the Polish food industry. As a result, in 2009 the value of the sold production 
of food products and beverages at constant prices increased by $3.8 \%$ on the previous year. An upward trend of output was also observed in 2010, the value of the sold production at constant prices increased by $4.6 \%$.

Figure 4. Growth rate of the sold production of the food industry ${ }^{\mathrm{a}}$ (constant prices), in \%

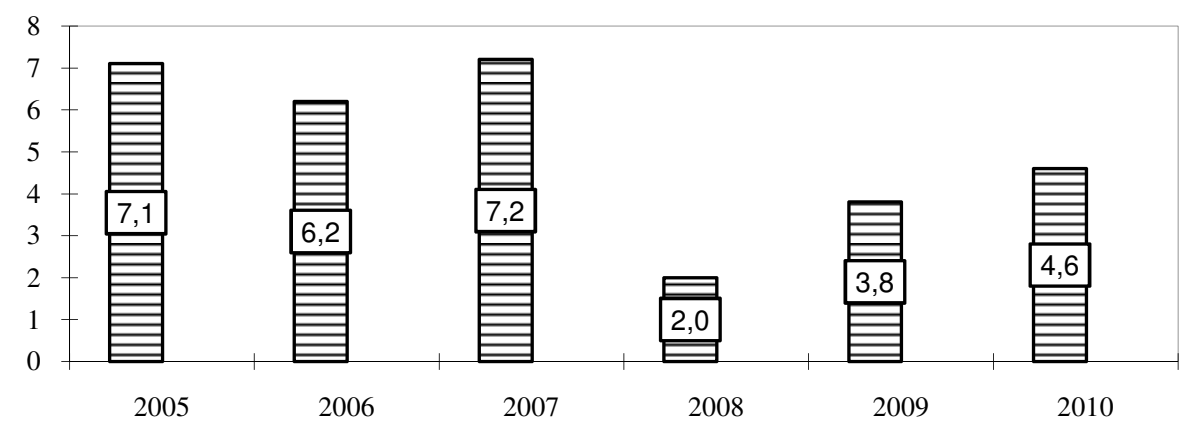

a the data concern all producers (including micro-enterprises and small businesses) of food and beverages (excluding tobacco products)

Source: own study based on Biuletyn Statystyczny (Statistical Bulletin), GUS (2005-2010), relevant issues.

As it has already been mentioned, consumer demand was less responsive to crisis developments than Poland's economy as a whole. Food demand proved to be even more resistant to such developments, as reflected in movements in retail sales of food, beverages and tobacco products. Such sales at constant prices augmented by $4.5 \%$ in 2007 and by $3.6 \%$ in 2008 (following a decline in the $3^{\text {rd }}$ and $4^{\text {th }}$ quarters of 2008), going up by $4.8 \%$ in 2009. A marked fall in such sales was not observed until 2010 when they dropped by $1.9 \%^{3}$, but that last development shows that the demand situation in the domestic food market continues to be uncertain and relatively unstable. Although foodstuffs represent basic consumer goods characterised by a low income elasticity of demand, it is not very realistic to assume that sales in the Polish market in food and beverages will continue to grow as fast as in previous years.

Therefore, an important factor driving the development of the Polish food sector, i.e. a relatively rapid rise in the capacity of the domestic market, has diminished in importance. At the same time, it shows that expanding output of the food industry is increasingly sold on foreign markets, and

\footnotetext{
${ }^{3}$ The assessment of movements in retail sales of food products is based on data published in relevant issues of Biuletyn Statystyczny (Statistical Bulletin), GUS, 2009-2011.
} 
the share of exports in total sales has been steadily improving. In 2010 as much as $26.6 \%$ of the production of the Polish food industry was sold in foreign markets, more than double the figure noted prior to Poland's accession to the European Union. It may pose a threat to the sector if major purchasers of Polish food are in recession, which was the case during the recent crisis, when strong recessions hit countries such as Germany, the United Kingdom, Ukraine and Russia. Adverse effects were mitigated by a significant weakening of the Polish currency, enhancing the profitability of exports and reducing that of imports, which prevented a plunge in exports and a further reduction in current account surplus due to recessions faced by trading partners and resulted in a mere slowdown.

Figure 5. Percentage share of exports in total sales of the food industry

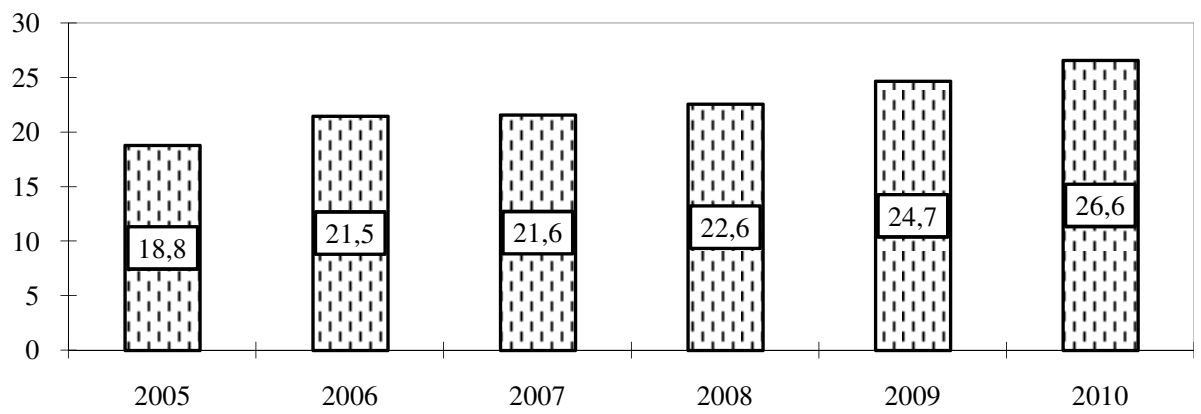

Source: own study based on unpublished data of GUS and CAAC (Centrum Analityczne Administracji Celnej - Analytical Centre of Customs Administration).

The global economic crisis caused a dramatic but temporary drop in the growth rate of the output of the food industry, observed from mid-2008 to mid-2009. However, it was a short-term slowdown as the second half of 2009 witnessed another upturn. It was hardly a definite recovery since in the first months of 2010 food production increased very slowly. But the subsequent months of 2010 saw a steady rise in the output of the food industry and confirmed a production upswing in the sector in question.

\section{Foreign trade in agri-food products}

Soon Poland will have been a European Union Member State for seven years. It is now clear that Poland's integration into the Community structures proved to be very favourable for Polish foreign trade in agri-food products. Food producers, successfully using their competitive advantages, 
mainly prices and quality, managed to significantly enhance their competitive position in the enlarged EU market.

An upturn in Polish foreign trade in agri-food products was observed immediately after EU accession. Between 2005 and 2006, agri-food exports expanded much more quickly than imports. The years 2007-2008 witnessed a continued growth in Poland's agri-food trade, but with imports more buoyant than exports. Owing to such movements in foreign trade flows, trade surplus improved in the first years of membership (from EUR 0.5 billion in 2003 to EUR 2.1 billion in 2006) and then went down (to EUR 1.3 billion in 2008). Those trends changed in the face of the global economic crisis (although the response to the crisis was still delayed in this area): in 2009 the value of food exports and imports dropped by $1.3 \%$ and 9.7\% respectively, which again improved agri-food trade balance (up to EUR 2.2 billion).

Table 1. Foreign trade in agri-food products

\begin{tabular}{|c|c|c|c|c|c|c|}
\hline Specification & 2005 & 2007 & 2008 & 2009 & 2010 & $\frac{2010}{2003}$ \\
\hline Agri-food exports & $7,028.0$ & $9,942.5$ & $11,421.6$ & $11,277.6$ & $13,507.2$ & 336.8 \\
\hline of which: to the $\mathrm{EU}^{\mathrm{a}}$ & $5,190.8$ & $8,001.4$ & $9,218.1$ & $9,066.9$ & $10,705.7$ & 409.1 \\
\hline Agri-food imports & $5,373.5$ & $7,972.3$ & $10,088.7$ & $9,111.0$ & $10,921.1$ & 307.0 \\
\hline of which: from the $\mathrm{EU}^{\mathrm{a}}$ & $3,388.1$ & $5,347.4$ & $7,023.0$ & $6,320.4$ & $7,481.9$ & 343.8 \\
\hline \multicolumn{7}{|l|}{ Agri-food trade balance } \\
\hline & $1,654.5$ & $1,970.2$ & $1,332.9$ & $2,166.6$ & $2,586.1$ & 570.2 \\
\hline of which: with the EU ${ }^{\mathrm{a}}$ & $1,802.7$ & $2,654.0$ & $2,195.1$ & $2,746.5$ & $3,223.8$ & 731.3 \\
\hline
\end{tabular}

Source: own study based on unpublished CAAC data.

The data on foreign trade in agri-food products in 2010 are also very favourable. The value of food trade jumped by almost $20 \%$, i.e. exports reached a record-high of EUR 13.5 billion, whereas imports augmented to EUR 10.9 billion. There was a further increase in agri-food trade surplus. In 2010 it amounted to nearly EUR 2.6 billion, up by over $19 \%$ on the previous year. This reappearance of an upward trend of exports mitigates somewhat the consequences of the recent decline in domestic demand for food products, unlike the years when the crisis was at its worst and rising domestic demand alleviated the effects of reduced export sales.

The poorer results of foreign trade in agri-food products in 2008 and 2009 stemmed from a combination of many factors. Obviously, they followed the global economic crisis, but other important developments included the rapid appreciation of the zloty noted until mid-2008, a fall in world prices for agri-food products in the second half of 2008 and a fading 
export potential of the two sectors subject to production quotas, i.e. the milk and sugar industries. Despite that temporary decline, Poland's foreign trade in agri-food products has expanded tremendously during membership of the EU, which reflects high competitiveness of Polish producers.

Figure 6. Foreign trade in agri-food products (EUR million)

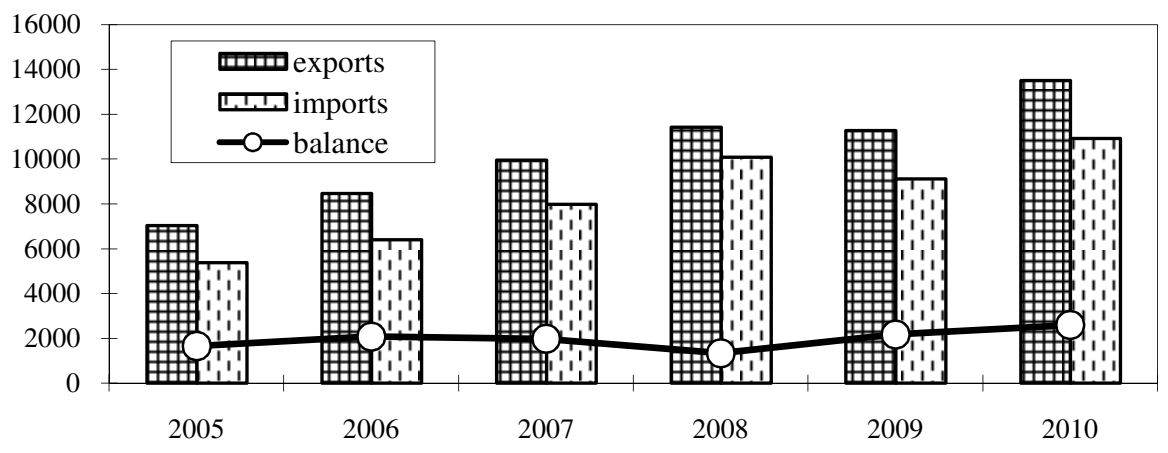

Source: own study based on unpublished CAAC data.

The economic and financial performance of the food industry

The reduced production activity of food producers during the global economic crisis was reflected in the financial performance of the food industry. In 2008 the net profit of the industry in question plummeted from PLN 6.5 billion to PLN 4.1 billion, i.e. by 37\%. At the same time, in 2008 the equity of food businesses shrank by $1 \%$, whereas it had increased by an annual average of ca. $10 \%$ in previous years. It was accompanied by a considerable rise (by PLN 1 billion) in long-term debt, thus deteriorating the long-term debt/equity ratio.

The considerable fall in net profit involved a decline in profitability indicators. In 2008 those were an average of 1.5 to 2 percentage points lower than in 2007, although still above the 2003 levels. The abovementioned movements were followed by a drop in return on equity (ROE) by one-third, but it continued to exceed the yields from alternative capital uses such as bank deposits and Treasury bonds. Greater borrowing costs also significantly contributed to the worsened financial results of the food industry as relative financial costs nearly doubled and their increase was only one-third lower than the fall in profitability indica- 
tors. Another cause of the decline in the financial performance of the food industry was a rising share of material, energy and labour costs in the selling price.

Table 2. Economic and financial performance of food enterprises

\begin{tabular}{|c|c|c|c|c|c|}
\hline Specification & 2005 & 2007 & 2008 & 2009 & 2010 \\
\hline Net profit (PLN billion) & 4.4 & 6.5 & 4.1 & 8.1 & 7.7 \\
\hline Equity (PLN billion) & 36.4 & 44.8 & 44.4 & 51.5 & 53.8 \\
\hline Long-term debt (PLN billion) & 5.1 & 5.8 & 6.8 & 9.1 & 5.2 \\
\hline $\begin{array}{l}\text { Profitability as a percentage share of } \\
\text { net income }\end{array}$ & & & & & \\
\hline - gross profit & 4.41 & 5.25 & 3.44 & 5.56 & 5.57 \\
\hline$-\quad$ net profit & 3.54 & 4.25 & 2.64 & 4.73 & 4.66 \\
\hline - capital accumulation ${ }^{\mathrm{a}}$ & 7.05 & 7.28 & 5.61 & 7.64 & 7.68 \\
\hline$-\quad$ operating surplus $^{\mathrm{b}}$ & 9.25 & 9.63 & 8.99 & 10.53 & 9.90 \\
\hline $\begin{array}{l}\text { ROE, i.e. net profit as a percentage share } \\
\text { of equity }\end{array}$ & 11.99 & 14.15 & 9.29 & 15.68 & 14.26 \\
\hline $\begin{array}{l}\text { Financial costs as a percentage share of } \\
\text { net income }\end{array}$ & 1.33 & 1.36 & 2.58 & 2.07 & 1.31 \\
\hline Liquidity $^{\mathrm{c}}$ & 1.27 & 1.30 & 1.23 & 1.33 & 1.33 \\
\hline $\begin{array}{l}\text { Share of enterprises reporting } \\
\text { net profits }(\%)\end{array}$ & & & & & \\
\hline - in the total number of companies & 78.4 & 83.8 & 73.2 & 82.9 & 82.7 \\
\hline - in the total sales of the industry & 85.8 & 90.1 & 76.4 & 86.5 & 87.7 \\
\hline
\end{tabular}

${ }^{a}$ net profit + depreciation; ${ }^{b}$ gross profit + depreciation + financial costs;

${ }^{c}$ ratio of current assets to short-term liabilities

Source: own study based on unpublished GUS data.

The deterioration in the financial standing of the sector in question in 2008 is also reflected in a lower proportion of profitable companies (down from $84 \%$ to $73 \%$ ) and a substantial drop in their share in the total sales of the industry (from $90 \%$ to $76 \%$ ), worsened liquidity (the current ratio down from 1.30 to 1.23) similar to the 2003-2004 levels, as well as in a lower share of equity in funding current operations.

Fortunately, the deterioration in the economic and financial performance of the food industry was temporary. In the years 2009-2010 the results of food businesses were not only better than in 2008, but they reached a peak. In 2009, the profit of food producers nearly doubled. The similar amount of net profit was generated in 2010. Net profitability (return on sales) was $4.73 \%$ in 2009 and $4.66 \%$ in 2010, capital accumulation (cash flow) reached $7.6 \%$ and $7.7 \%$ respectively. Return on equity (ROE) improved to about $15 \%$. Liquidity went up to 1.33 in the years 2009- 
-2010. All the above-mentioned developments suggest that the Polish food industry was rather resilient to the crisis and that food businesses enhanced their financial standing after a temporary decline.

\section{Investment in the food industry}

Until 2008, the food industry experienced an investment boom driven by integration into the European Union. In 2008 investment in the sector in question totalled ca. PLN 7.6 billion (at 2003 prices), slightly (approx. 5\%) more than in 2006-2007 and nearly as much as 50\% more than prior to accession to the European Union. The investment ratio was also high (1.58), even above the 2005-2007 levels. In 2008, in connection with the onset of the crisis, there were symptoms pointing to a possible decline in investment activity in the whole sector. According to GUS data, in 2008 the value of investment projects undertaken in the food industry dropped by over one-fourth. The downward trend continued in 2009 and then in 2010, with the value of investment falling to PLN 6.0 billion and PLN 6.2 billion respectively. The investment ratio also showed a decrease. In the years 2009-2010 it was about 1,2. But investment activity in the food industry can be expected to pick up again, as reflected in a mild increase (by approx. 25\%) in the value of investments started in 2010.

Table 3. Investment in the food industry

\begin{tabular}{|l|r|r|r|r|r|r|}
\hline \multicolumn{1}{|c|}{ Specification } & $\mathbf{2 0 0 5}$ & $\mathbf{2 0 0 6}$ & $\mathbf{2 0 0 7}$ & $\mathbf{2 0 0 8}$ & $\mathbf{2 0 0 9}$ & $\mathbf{2 0 1 0}$ \\
\hline Investment in PLN billion & 6.2 & 7.1 & 7.2 & 7.9 & 6.6 & 6,7 \\
$-\quad$ at current prices & 6.0 & 6.8 & 6.8 & 7.3 & 6.0 & 6.2 \\
- $\quad$ at 2003 prices & 1.37 & 1.49 & 1.49 & 1.58 & 1.20 & 1.19 \\
\hline Investment ratio $^{\text {a }}$ & 1.9 & 2.1 & 2.5 & 1.9 & 1.5 & 1.9 \\
\hline Investments undertaken, PLN bil- \\
lion, at current prices
\end{tabular}

${ }^{a}$ investment/depreciation ratio

Source: own study based on Roczniki Statystyczne (Statistical Yearbooks) GUS (20052010), Biuletyn Statystyczny (Statistical Bulletin), GUS (No 1/2011).

The investment boom in the food industry observed during the integration into the EU was related to the necessary adjustments to the EU standards (particularly in the so-called sensitive sectors). As regards considerable investment activity in 2008, it resulted from the need to create sustainable foundations for enhancing the competitiveness of Polish food producers under conditions of rapid market development and export expansion. However, the crisis has made producers more cautious in their develop- 
ment-oriented decisions, which caused a substantial fall in the value of new investments and in the overall investment expenditure. Thus, it poses no threat to further growth in the sector in question as the value of investment decreased from a very high 2008 level; naturally, provided that it is not a long-term decline.

\section{CONCLUSIONS}

Opinions on whether a crisis is already over or not vary widely. Some perceive recovering from recession and emerging from the trough as the end of a crisis. For others, a crisis ends when its roots have been eliminated, which is very difficult to determine on account of their complexity and severity. Announcing a recovery prematurely may result in withdrawal from remedial measures too soon and the failure to remove the underlying causes of a crisis, thus in a gradual reappearance of crisis developments in the economy. At the same time, recognising a post-crisis situation too late involves a risk of delayed actions by central banks and governments in limiting money inflows and maintaining low interest rates, thus pushing up the inflation rate (Szymański 2010, pp. 15-16).

As far as the recent crisis is concerned, opinions vary as well. Various symptoms of an economic upswing are pointed to ever-more frequently, but there are also voices that those may be mere effects of stimulating growth by the largest economies. The euphoria related to recovering from the crisis is gradually squeezing out previous opinions that comprehensive systemic and structural reform are necessary. According to Szymański, however, so far only "some detonators of crisis developments have been neutralised, leaving the explosives intact, and under certain circumstances those may easily be triggered again" (Szymański 2010, p. 32).

Bearing the above in mind, it is difficult to unambiguously say whether Poland is already emerging from the trough and whether the observed recovery is a long-term development. However, there are many indications that this is the case. The performance of Poland's entire economy during the global economic crisis at its worst confirmed favourable assessments of the economy and of its significant resilience to cyclical threats. The Polish food industry and the food sector as a whole proved to be even less sensitive to the global crisis. Those were the sections which only experienced a temporary slowdown in output, domestic demand and exports, accompanied by a considerable fall in imports and investment. After a short-term deterioration in performance, the food industry is now flourishing with record-high economic and financial results. An upswing is also observed in Poland's whole economy. Those are developments indicating a reappeara- 
nce of upward trends in the Polish food industry, although the growth rate is likely to be lower than in the years of Poland's integration into the European Union.

The situation of the Polish food industry and of the food sector as a whole is not yet stable and certain. The business environment continues to be turbulent. The uncertainty results from the lack of consumer optimism, which pushes down retail sales of food and beverages. The instability also stems from high unemployment, major exchange rate fluctuations, high public debt in Poland as well as in some euro-area countries, and from the fact that Poland's main trading partners recover from the recession slowly (Urban 2010). Furthermore, Chechelski points to the failure of domestic enterprises to adapt to global market rules, insufficient intensification of competitive measures, conservative business strategies and limited progress in restructuring processes (Chechelski 2009, p. 52). Those are factors which will make the coming years difficult for Poland's economy as a whole and for the Polish food industry. One can only hope that implications of such developments will not result in an economic crisis.

\section{LITERATURE}

Biuletyn Statystyczny (2008-2010), GUS, relevant issues, Warsaw.

Chechelski P. (2010), Wptyw kryzysu na globalna gospodarkę żywnościowa, "Komunikaty Raporty Ekspertyzy" nr 543, IERiGŻ-PIB, Warszawa.

Rocznik Statystyczny (2003-2010), GUS, Warszawa.

Skawińska E. (ed.) (2002), Konkurencyjność przedsiębiorstw - nowe podejście, PWN, Warszawa.

Sobiecki R. (2010), Kryzysy rolne a bezpieczeństwo rolne, [in:] R. Sobiecki, J.W. Pietrewicz (ed.), Przedsiębiorstwo a kryzys globalny, Szkoła Główna Handlowa, Warszawa.

Szczepaniak I. (ed.) (2009), Ocena konkurencyjności polskich producentów żywności po akcesji do Unii Europejskiej, Multi-annual Programme Report nr 150, IERiGŻ-PIB, Warszawa.

Szczepaniak I. (2009), Wptyw światowego kryzysu gospodarczego na konkurencyjność polskich producentów żywności, [in:] R. Borowiecki, A. Jaki (ed.), Wyzwania restrukturyzacyjne w obliczu globalnego kryzysu gospodarczego, Uniwersytet Ekonomiczny w Krakowie, Kraków.

Szymański W. (2010), Kiedy i co po kryzysie?, [in:] R. Sobiecki, J.W. Pietrewicz (ed.), Przedsiębiorstwo a kryzys globalny, Szkoła Główna Handlowa, Warszawa.

Szymański W. (2009), Kryzys globalny. Pierwsze przybliżenie, Diffin SA, Warszawa.

Urban R. (2009), Światowy kryzys finansowy, „Przemysł Spożywczy”, nr 1.

Urban R. (2010), Polski przemyst spożywczy w okresie światowego kryzysu gospodarczego, „Przemysł Spożywczy”, nr 7-8. 
Warszawska Giełda Papierów Wartościowych, notowania (2011), http://www.money.pl (state on $18^{\text {th }}$ February).

World Economic Outlook UPDATE (2011), International Monetary Fund, Washington D.C. (USA), http://www.imf.org (state on $25^{\text {th }}$ January).

Wiatrak A.P. (2008), Zewnętrzne uwarunkowania konkurencyjności przedsiębiorstw sektora agrobiznesu, [in:] I. Szczepaniak (ed.), Wybrane aspekty konkurencyjności polskich producentów żywności, Multi-annual Programme Report nr 110, IERiGŻ-PIB, Warszawa.

Wptyw kryzysu ekonomiczno-finansowego na sytuacje sektora rolnożywnościowego $w$ Polsce (2010), report commissioned by the FAO and prepared by the team of experts: A. Kowalski, J. Kulawik, Z. Floriańczyk, L. Goraj, I. Szczepaniak, B. Wieliczko, J. Drożdż, A. Kagan, W. Łopaciuk, M. Wigier, IERiGZ̈-PIB, Warszawa. 